\title{
Import Substitution of Software in the Government Procurement Sphere
}

\author{
Kazanskaya A.Yu. \\ Southern Federal University \\ Taganrog, Russia \\ akazanskaya@sfedu.ru
}

\author{
Nalesnaya Ya.A. \\ Southern Federal University \\ Taganrog, Russia \\ jana_n@list.ru
}

\begin{abstract}
The research identifies the main problems of the domestic software introduction in the interests of public authorities. First of all, in addition to consumer qualities, there is an acute issue of reliability and safety of foreign products which will be used. Import substitution in this case goes in two directions: full import substitution in departmental and state information systems and partial import substitution of separate elements of systems, in particular, import substitution of office software.
\end{abstract}

Keywords-import substitution; government procurement; software; domestic counterpart.

\section{INTRODUCTION}

The Russian state policy of import substitution is inherently protectionist. It consists of deliberately restricting imports with a use of various financial and administrative instruments [1]. It should be noted that many developed countries have elements of protectionism in their politics, and in this matter Russian Federation politic strategy is not original. For example, in the United States since 1933, the socalled "Buy American Law" [2], requiring federal funds to purchase only American-made goods, has been in force. In Brazil the state program "T1 Mayug" was adopted in 2012. It was designed to support national software developers financially through the government procurement system and it did not allow the participation of foreign companies [3]. Similar measures were taken in China: Art. 10 of the "Law on Public Procurement in the People's Republic of China", adopted on June 29, 2002, obliges government agencies to buy only Chinese goods and services [4].

On the one hand, such a policy stimulates the national producer, allowing start-ups to get on their feet, and for mature companies to get a share of domestic demand easily. But on the other hand, there is a considerable danger in it: in the absence of natural competition with world market participants, based exclusively on the goods quality struggle, the national producer does not invest in innovations and simply "parasitizes" on state subsidies.

The topic of import substitution is not new to Russia. According to a number of researchers [5,6,7], the country gained some positive experience after the 1998 crisis. The depreciation of the ruble and the multiple increase in prices for imported goods caused an increase in the volume and range of domestic production, followed by the consumption reorientation to Russian goods. In 2008-2009 The ruble devaluation became the catalyst for import substitution again. A feature of this stage was the localization of foreign production capacities in Russia in a number of industries. Currently, the next wave of import substitution is caused by economic sanctions and geopolitical risks. Today, the level of this task relevance has reached its maximum, since its solution affects various aspects of the internal and external security of Russia, which is based on information technologies as in other modern countries. Although large foreign developers, such as Microsoft, provide Russian government departments with access to the source codes of their programs, there is a risk of having undocumented "bookmarks" in their compiled versions. Such "bookmarks" are hidden from the user and provide an attacker with unauthorized access to the computer on which this program is used, and, accordingly, to the information stored on it.

The importance of IT for the economy is also confirmed by statistics. From 2000 to 2018 the global software market has grown almost 20 times: according to various estimates, today it ranges from 1-2 trillion dollars. USA [8, 9, 10]. The share of Russian exports in the market is extremely small only $0.5 \%$. At the same time, the dependence on imports is enormous: the share of foreign software and hardware used in Russian Federation varies from 60 to $95 \%$ in various industries. According to some reports [10], annually large foreign IT companies receive through license fees more than $40 \%$ of the Russian IT market total volume. In this share about $30 \%$ are state-owned organizations. As a result, the total cost of software ownership can be 5-6 times higher than the initial cost of its implementation.

In the spotlight of the foregoing, it is appropriate to study the problems of import substitution of software in the field of public procurement, to find out ways of reducing the imported software suppliers' dependence, to determine the role of the state in this problem solving. This article assesses the importsubstituting state policy, analyzes the state and problems of import substitution software in the field of public procurement. 


\section{ReseARCH Methodology}

The Russian Federation paid special attention to the import substitution strategy in 2014. The main reason for this was the simultaneous introduction of economic sanctions by a large number of states against Russian legal entities and individuals., Import substitution began to grow faster after the imposition of sanctions, as political leaders were faced with the task of increasing the national and economic security of the state., Regulatory legal acts and decisions in the field of import substitution began to be worked out intensively, and amendments to existing federal laws were introduced. [11] Since public procurement is one of the most powerful tools to stimulate production, political and economic processes, the state political leaders decided to support the import substitution strategy by turning to this instrument. The main reasons for this decision were:

- $\quad$ transparency of bidding,

- a unified information system in the field of procurement,

- $\quad$ open and accessible for viewing by the population, and, accordingly, publicity.

On January 1, 2016, the Federal Law of June 29, 2015 No. 188-FZ "On Amendments to the Federal Law of July 27, 2006 N 149-FZ "On Information, Information Technologies and the Protection of Information" and article 14 of the Federal Law of 05.04.2013 N 44- $\Phi 3$ "On the contract system in the field of procurement of goods, work, services to meet state and municipal needs" came into force. The process of public procurement of goods, works, and services underwent serious changes after the introduction of the aforementioned Federal Law [3]. All state and municipal bodies, state corporations "Rosatom" and "Roskosmos", governing bodies of the state extra-budgetary funds, as well as state and budget institutions, must carry out procurement in accordance with the requirements described in Article 3 of the Federal Law dated 05.04.2013 N 44-FZ [12]. From January 1, 2016, for public procurement it is necessary to use domestic software, mainly included in the unified register of Russian programs for electronic computers and databases (hereinafter referred to as the Russian software register), in accordance with the Decree of the Russian Federation Government from November 16, 2015, N1236 [13]. The Ministry of Telecom and Mass Communications of the Russian Federation is the authorized federal executive body for creation and formation of the register. The Russian software register is a classified list of software products. At the beginning of 2019 the register included 5082 software tools.

\section{RESULTS}

When making public procurement, the customer has the right not to establish a ban on the admission of foreign software in two cases (according to [13]):

- when there is no information in the unified registry about software that corresponds to the same class of software as the software planned for purchase;
- when the software, information about which is included in the register and which corresponds to the same class of software as the software planned for purchase, in terms of its functional, technical and (or) operational characteristics does not meet the requirements for the software planned for purchase established by the customer. [13]

If domestic software from the register does not fit the state customer for its functional, technical and (or) operational characteristics, then it is necessary to prepare the rationale for the foreign software use further and to place it in a single procurement information system at the same time as posting a notice on the procurement.

The procedure for preparing the justification was also approved by [13]. The justification should fully comply with the structure approved by the Government Decree, and the arguments given should be supported, if necessary, by references to the documentation for the requested software, otherwise the state customer may arise questions from the Federal Antimonopoly Service, and also requests for clarification may be formed. In other cases, complaints may be submitted in a single information system in the field of procurement from individuals and legal entities. Complaints will be further dealt with by the Federal Antimonopoly Service. The complaint may be considered unfounded, substantiated, partially substantiated. If the Federal Antimonopoly Service of Russia determines that the complaint is partially substantiated or justified, the order is issued to the customer to amend the procurement documentation, and the responsible persons on the part of the state customer who are responsible for the commission of this illegal action are brought to administrative responsibility.

\section{DISCUSSION}

What are the main difficulties a state customer may encounter while forming a technical task for the acquisition of any services, including services for the creation of state information systems? Particular attention in the process of a technical task formation is paid to the compatibility of systemwide and special software, including information security software [14].

For example, the most commonly used operating system is the Windows operating system, and, accordingly, the software for creating and editing various documents is Microsoft Office. Microsoft Office is an imported software and, accordingly, is not included in the register, though in this register there is another software that corresponds to the same class as the above - My office. But it does not meet the requirements and functional characteristics for the software of this class, the user cannot fulfill all the tasks assigned to it in it, not all the required special software is compatible with this software package. "My office" requires serious improvements from the developers. In addition, the state customer often has to buy equipment for previously purchased equipment, in accordance with which the software purchased as part of public procurement should be compatible with the software installed on previously purchased equipment. 
the field of public procurement is to ensure the economic security of the state, stimulate scientific and technological progress, and increase the competitiveness of the domestic companies' development. The improvement of the domestic developments competitiveness is achieved due to the lower cost of acquiring domestic software in comparison with foreign counterparts, and its better adaptation to Russian realities [16]. For example, a domestic developer will respond to the amendments and update the software version more quickly, when the legislation of the Russian Federation is changing. Russian developer not only provides technical support for his software in the quickest manner, but also takes into account the wishes of the state customer, that is, changes initiated by the customer can be made to the developed product. It is worth noting that those developed companies that set goals for the software development, spent more resources and resources before amendments to the law had received the necessary competitive advantages and can now compete with foreign developers at the high level. [10]

We should note the following disadvantages in software import substitution in the field of public procurement. There are no Russian products alternatives with comparable functional characteristics for all classes of software, not all special software is compatible with system-wide domestic software, there are risks of failures of various customer systems due to the use of raw Russian products.

\section{CONCLUSIONS}

* Having examined the above examples, we can conclude that the main advantages of import substitution of software in

TABLE I. IMPORT SUBSTITUTION PROJECTS LAUNCHED IN 2015-2019

\begin{tabular}{|c|c|c|c|c|c|}
\hline Customer & Contractor & $\begin{array}{l}\text { Foreign IT solution } \\
\text { replaced }\end{array}$ & Domestic or open source solution replaced the foreign & $\begin{array}{c}\text { Project } \\
\text { budget, mln } \\
\text { rubles }\end{array}$ & $\begin{array}{l}\text { Year of } \\
\text { project } \\
\text { start }\end{array}$ \\
\hline $\begin{array}{l}\text { Moscow City } \\
\text { Court }\end{array}$ & Krok & No data & $\begin{array}{l}\text { Aquarius Servers, Postgre SQL DBMS, WSO2 } \\
\text { integration bus, Kaspersky antivirus Krok application } \\
\text { subsystems, Optima-V planetary scanners (manufactured } \\
\text { in Irkutsk) }\end{array}$ & 2468 & 2015 \\
\hline $\begin{array}{l}\text { Moscow Region } \\
\text { Government }\end{array}$ & Softline & $\begin{array}{l}\text { Depo, Basalt SPO, } \\
\text { TONK Group of } \\
\text { Companies, etc. MS } \\
\text { Windows, MS Office, }\end{array}$ & OS Alt & 1820 & 2017 \\
\hline $\begin{array}{l}\text { Federal Tax } \\
\text { Service of } \\
\text { Russia }\end{array}$ & $\begin{array}{l}\text { GNIVTS Federal Tax } \\
\text { Serv, IBS, Elvis-Plus, } \\
\text { Basalt SPO and others }\end{array}$ & MS Windows & OS Alt & 982 & 2017 \\
\hline Transneft & Galaxy & SAP & ERP “Galaxy”, Galaxy EAM and Galaxy AMM & 917 & 2017 \\
\hline Rosreestr & $\begin{array}{l}\text { AT Consulting, } \\
\text { Transdata }\end{array}$ & $\begin{array}{l}\text { Oracle DBMS (IS EGRP } \\
\text { and AIS GKN) }\end{array}$ & DBMS PostgreSQL (EGRON, second and third turn) & 365 & 2015 \\
\hline $\begin{array}{l}\text { The Post of } \\
\text { Russia }\end{array}$ & Binom & Microsoft Office & MyOffice & 358 & 2019 \\
\hline $\begin{array}{l}\text { Russian } \\
\text { Railways }\end{array}$ & Servionica & $\begin{array}{l}\text { VMware Horizon, Citrix } \\
\text { Xen Desktop }\end{array}$ & RUSTEC & 348.5 & 2017 \\
\hline
\end{tabular}

An important factor complicating the transition to domestic software systems is also the need for personnel retraining to work with a domestic software, which is far from always easier to use than the foreign alternative.

In addition, it is not economically profitable for Russian companies to invest resources into the development or refinement of all software classes, because there are popular foreign counterparts on the market that users are used to and who they trust. In such cases, only top-level political decisions can have an effect.

The main reasons of the sluggish dynamics of import substitution: 
[4] The Government Procurement Law of the People's Republic of China. URL: http:// www. npc . gov. cn/englishnpc/Law/200712/06/content_1382108.htm (дата обращения: 18 . 03.2016).

1) IT executives in government agencies are afraid to switch to domestic DBMSs and server operating systems. The reason for the fear is that migration to a new product is a process that takes months and is fraught with failures.

2) The transition to a new solution requires financial resources. IT managers are not always able to convincingly argue why the department should migrate from one product that suits them perfectly to another, completely similar. If we ignore the policy of import substitution, this is simply a costs doubling of resolving the same issue - at least that is how the Accounts Chamber and other control bodies can assess the situation.

3) The problem is complicated by the fact that in some cases the replacement of basic software will lead to the need to process the entire federal state information system. This will entail re-testing, integration, staff training, etc.

4) No less important is that in the information field there are practically no examples of successful projects related to the replacement of foreign software with Russian. There is no public experience that IT executives could focus on.

The results from the current state policy of import substitution cover the emerging disadvantages, but, nevertheless, they cannot be left unattended while future decisions developing in the field of creation and implementation of domestic software at the level of state authorities and business. It will take a lot of time, accumulation of investment resources, and most importantly, the chosen course continuation of the import substitution state economic policy in the field of information technology. All of the above measures used in a single complex will allow to achieve the necessary level of information sovereignty and information security of the state.

\section{References}

[1] Evgeny S. Ogurtsov, Mikhail N. Korsakov. Import substitution as a long-term trend to provide economic growth of the russian economy. 4th International Multidisciplinary Scientific Conference SOCIAL SCIENCES \& ARTS SGEM, 2017

[2] Law «Buy American Act» . URL: http://www. international.gc. ca/sell2usgov-vendreaugouvusa/procurement-marches/buyamerica. aspx?lang=eng; http://d-russia. ru/ gosudarstvennaya-zakupka-po-opytssha. html (дата обращения: 18 . 03.2016).

[3] URL: http://thebrazilbusiness . com/article/overview-of-ti-maior (дата обращения: 18 . 03.2016).
[5] Doroshenko M. E., Skripkin K. G. Software National Market Development: Public Policy Alternatives. FORSIGHT. National Research University Higher School of Economics (Moscow) - 2013. V.7 No.13. - P. 44-57. ISSN: 1995-459X

[6] Kadochnikov P. A. Analysis of import substitution in Russia after the 1998 crisis. M.: IET, 2006.148 s.

[7] Kalyuzhny K. A. Status and prospects of import substitution in the Russian IT industry. // The science. Innovation Education. - 2016. [Electronic resource]. - URL: https://cyberleninka.ru/article/n/sostoyanie-i-perspektivyimportozamescheniya-v-rossiyskoy-it-otrasli (accessed: 08.25.2019).

[8] St. Petersburg International Economic Forum . (2015) National Technological Initiative .Briefing . Available from URL: http://forumspb .com/bfx-cc/system/uploads/files/site_session_attr/stenogram_ru/631/ 1129_ru . pdf [Accessed: 18.08.2019] .

[9] IDC \#RUS3520. (2014) Review and assessment of trends of world and Russian IT markets . Available from URL: http://www. rusventure . ru/ru/ programm/analytics/docs/obzor_it. pdf [Accessed: 18.08.2019]

[10] TAdviser, Advantages of replacing foreign IT solutions with domestic ones [Electronic resource]. URL: http://www.tadviser.ru/index.php/Article:Advantages_replacement_of_ foreign_IT_resolutions_domestic. (Date accessed: 12/25/2018)

[11] Akulinicheva A. V., Vasiliev R. P. Import substitution, the benefits of reorienting commodity flows in international trade during the extension of sanctions // Young Scientist. - 2016. - No. 10. - S. 583-586. [Electronic resource]. - URL: https://moluch.ru/archive/114/29636/ (accessed: 12/25/2018).

[12] Federal law dated 05.04.2013 N 44-Ф3 “On the contract system in the field of procurement of goods, works, services to ensure state and municipal needs". [Electronic resource]. - URL: https://base.garant.ru/57509114/ (accessed: 12/25/2018).

[13] Decree of the Government of the Russian Federation of November 16, $2015 \mathrm{~N}$ 1236. [Electronic resource]. - URL: http://base.garant.ru/71252170/ (date of access: 12.25.2018).

[14] Pavlov Artem Yu., Elena A. Kobets, Evgeniy S. Ogurtsov, Samonova K.V. Formation of a complex of indicators for assessing high-tech import substitution projects. 2017 IEEE VI Forum "'Strategic Partnership of University and Enterprises of Hi-Tech Branches" (Science, Education, Innovations)

[15] Sergeeva I.I., Sergeeva E.P. Import Substitution Of Software: Modern Realities. Education And Science Without Borders: Fundamental And Applied Research. Oryol State University of Economics and Trade (Oryol) - 2016. No. 3. - P. 342-345. ISSN: 2500-249X

[16] Makarenya T.A., Stash S.V., Sinelnikov T.T., Simchenko N. Environmental and economic problems of socioeconomic system development at the municipal level // 17th International Multidisciplinary Scientific GeoConference SGEM 2017, 2017

[17] Aleksandr S. Kuznetsov. Russian Professor's meeting. Russian Journal of Physical Education and Sport. Pp. 2019, 14(1), 17-22. DOI: 10.14526/2070-4798-2019-14-1-18-24 